\title{
Association of ACE, VEGF and CCL2 gene polymorphisms with Henoch-Schönlein purpura and an evaluation of the possible interaction effects of these loci in HSP patients
}

\author{
Tahereh Mohammadian, ${ }^{1, B,}$, Mortaza Bonyadii, A-F, Elahe Nabat ${ }^{1, B}$, Mandana Rafeey3, B \\ ${ }^{1}$ Center of Excellence for Biodiversity, Faculty of Natural Sciences, University of Tabriz, Tabriz, Iran \\ ${ }^{2}$ University of Tabriz \\ ${ }^{3}$ Liver and Gastrointestinal Research Center, Tabriz University of Medical Sciences, Tabriz, Iran \\ A - research concept and design; $B$ - collection and/or assembly of data; $C$ - data analysis and interpretation; \\ $D$ - writing the article; $E$ - critical revision of the article; $F$ - final approval of article
}

Address for correspondence

Mortaza Bonyadi

E-mail: jabbarpour@tabrizu.ac.ir

Funding sources

None declared

Conflict of interest

None declared

Acknowledgements

Authors would like to thank all patients for

their contribution to the work.

Received on August 17, 2015

Revised on December 09, 2015

Accepted on April 26, 2016

\begin{abstract}
Background. Henoch-Schönlein purpura (HSP) is a multisystem, small vessel, leucocytoclastic vasculitis. It is predominantly a childhood vasculitis, rarely reported in adults. Studies have shown that several different genetic factors such as genes involved in inflammatory system and renin-angiotensin system (RAS) are important in the pathogenesis of Henoch-Schönlein purpura.
\end{abstract}

Objectives. The purpose of this study was to evaluate the independent effect of 3 gene polymorphisms including CCL2-2518 C/T, VEGF-634G/C and ACE(I/D) with HSP disease and their possible joint interactions in developing the disease.

Material and methods. In this case-control study 47 HSP cases and 74 unrelated healthy controls were enrolled for evaluation. All individuals were genotyped for CCL2-2518C/T, VEGF-634G/C and ACE(I/D) gene polymorphisms. The possible association of these polymorphisms with susceptibility to develop HSP disease independently and in different joint combinations was evaluated.

Results. The frequencies of TT genotype and Tallele of CCL2-2518C/T gene polymorphism and CC genotype and Callele of VEGF-634G/C gene polymorphism were significantly high in HSP children ( $p$-values $=0.005$ and $=0.007$ respectively). Interestingly, studying the joint interaction of these 2 genotypes (CC genotype of VEGF G-634C and TT genotype of CCL2 (-2518T) in this cohort showed a more significant effect in the development of the disease $(p<0.000,0 R=6.009)$. The frequency of TT genotype of $C C L 2$ gene when combined with II genotype of ACE gene in HSP children was significantly higher $(p<0.000,0 R=4.213)$.

Conclusions. The results of this pilot study provide evidence of the possible gene-gene interaction effects of CCL2, VEGF and ACE genes in developing HSP disease.

Key words: CCL2, VEGF, Henoch-Schönlein purpura, gene-gene interaction effect, ACE

DOI

$10.17219 /$ acem $/ 62896$

Copyright

Copyright by Author(s)

This is an article distributed under the terms of the

Creative Commons Attribution Non-Commercial License

(http://creativecommons.org/licenses/by-nc-nd/4.0/) 
Henoch-Schönlein purpura (HSP) is a leukocytoclastic vasculitis of small blood vessels usually occurring between 3 and 15 years but it could be developed at any age. This systemic vasculitis is characterized by palpable purpura, arthritis or arthralgias, gastrointestinal and renal involvement. ${ }^{1,2}$

It has been shown that multiple different genes and their interactions with environmental factors are involved in the susceptibility to HSP. ${ }^{3}$ Therefore, genetic background is an important factor in the pathogenesis of this immune-mediated inflammatory disease. ${ }^{4}$

Inflammatory mediators such as transforming growth factor (TGF)-b, vascular endothelial growth factor (VEGF) and some pro-inflammatory chemokines increase in the serum of HSP patients. ${ }^{5-7}$

The MCP-1/CCL2 produced by macrophages, endothelia and some other cells is chemo-attractant cytokine that has important role in immune-regulatory and inflammatory processes by attracting monocytes to the region of inflammation. ${ }^{8}$ MCP-1-2518 polymorphism is located in promoter region of the gene and its role in the development of HSP disease has been evaluated previously. ${ }^{9}$

Vascular endothelial growth factor (VEGF) is a cytokine with angiogenic activity which could have a crucial role in inflammatory reaction in different disorders. It has been proposed that VEGF-634G/C polymorphism, which affects the expression level of the gene, could have an association with the development of the disease. ${ }^{10}$

Angiotensin I-converting enzyme (ACE) is a key component of the renin-angiotensin system. This system regulates vascular homeostasis and inflammation. Increasing the level of ACE leads to vascular inflammation due to cytokine release. ${ }^{11}$ Polymorphism of the ACE gene (I/D) and its role in HSP disease has been studied in patients from different populations. ${ }^{12,13}$

Considering that HSP disease is a complex disease involving different genetic factors, we planned to evaluate the possible associations of these polymorphisms with the susceptibility to HSP independently and in different joint combinations.

\section{Material and methods}

\section{Patients}

The studied population consisted of 47 patients (28 males and 19 females, with a mean age of 8.14 years) who were diagnosed by specialists for HSP. The control group consisted of 74 healthy adults with no renal, vasculitic, allergic or inflammatory diseases. The majority of patients (95.74\%) had palpable purpura. Gastrointestinal complications in $63.82 \%$ and joint pain in $44.68 \%$ of the patients were observed. This study was approved by the Ethics Committee of Tabriz University of Medical Science and an informed written consent was obtained from all patients' parents.

\section{Genetic analysis}

Genomic DNA was extracted from whole blood according to standard DNA extraction protocol. ${ }^{14}$

Each individual was genotyped for CCL2 -2518 C/T and $V E G F-634 \mathrm{G} / \mathrm{C}$ polymorphisms by polymerase chain reaction (PCR)-restriction fragment length polymorphism (RFLP) as described previously. ${ }^{15,16}$ In brief, to genotype for CCL2 -2518, the PCR product was digested by PvuII restriction enzyme. The PCR product from individuals with $\mathrm{C} / \mathrm{C}$ genotype was digested into $121 \& 172 \mathrm{bp}$. In individuals with T/T genotype $293 \mathrm{bp}$, the PCR product was left intact. ${ }^{15}$ In order to genotype for VEFG -634 polymorphism, the amplified fragments were digested with BsmfI restriction endonuclease. The GG genotype was cut into two fragments of 250bp and 93bp, while the CC genotype displayed a single fragment of 343bp. ${ }^{16}$

The I/D polymorphism in ACE gene was determined by applying PCR as described previously. ${ }^{17}$

Table1. Genotype and allele distributions of the patients and controls in 3 polymorphisms

\begin{tabular}{|c|c|c|c|c|}
\hline $\begin{array}{c}\text { Genotypes } \\
\& \text { alleles }\end{array}$ & \multicolumn{2}{|c|}{$\mathrm{N}(\%)$} & $\mathrm{p}$-value & $\begin{array}{l}\text { Odds } \\
\text { ratio }\end{array}$ \\
\hline VEGF-634G/C & case & control & & \\
\hline GG & $7(14.89)$ & $19(25.67)$ & $0.021^{*}$ & 0.507 \\
\hline GC & $27(57.45)$ & $45(60.81)$ & 0.347 & 0.870 \\
\hline $\mathrm{CC}$ & $13(27.66)$ & $10(13.51)$ & $0.007^{*}$ & 2.448 \\
\hline G & $41(43.62)$ & $83(56.08)$ & $0.036^{*}$ & 0.606 \\
\hline C & $53(56.38)$ & 65 (43.92) & $0.030^{*}$ & 1.650 \\
\hline CCL2 -2518C/T & case & control & & \\
\hline $\mathrm{CC}$ & $1(2.13)$ & $8(10.81)$ & $0.010^{*}$ & 0.180 \\
\hline $\mathrm{CT}$ & 15 (31.91) & 31 (41.89) & $0.057^{*}$ & 0.650 \\
\hline $\mathrm{TT}$ & 31 (65.95) & 35 (47.29) & $0.005^{*}$ & 2.159 \\
\hline C & $17(18.08)$ & $47(31.75)$ & $0.018^{*}$ & 0.474 \\
\hline $\mathrm{T}$ & 77 (81.91) & $101(68.24)$ & $0.015^{*}$ & 2.107 \\
\hline ACE I/D & case & control & & \\
\hline$\|$ & $14(29.79)$ & $16(21.62)$ & 0.109 & 1.538 \\
\hline ID & $16(34.04)$ & $28(37.84)$ & 0.295 & 0.848 \\
\hline DD & $17(36.17)$ & $30(40.54)$ & 0.336 & 0.831 \\
\hline I & $44(46.81)$ & $60(40.54)$ & 0.210 & 1.291 \\
\hline D & $50(53.19)$ & $88(59.46)$ & 0.183 & 0.775 \\
\hline
\end{tabular}

${ }^{*} p$-value less than 0.05 . 


\section{Statistical analysis}

All statistical analyses were performed by $\mathrm{R}$ ( $\mathrm{R}$ Core Team [2014]. R: A language and environment for statistical computing. R Foundation for Statistical Computing, Vienna, Austria. URL http://www.R-project.org/). We used logistic regression analysis in case-control studies. To evaluate gene-gene interaction, all possible subgroups were created and $\chi^{2}$ test was used to compare these groups.

\section{Results}

Analysis for CCL2 C-2518T showed that TT genotype and $\mathrm{T}$ allele of this polymorphism is significantly high in HSP patients ( $\mathrm{p}=0.005$ and 0.015 respectively), while the frequency of CC genotype and $\mathrm{C}$ allele in patients is less than that of control group (Table 1).

Genotypic and allelic analysis in VEGF -634G/C polymorphism showed significant difference between case and control group. $\mathrm{CC}$ genotype and $\mathrm{C}$ allele of this polymorphism is more frequent in patients $(\mathrm{p}=0.10$ and 0.018 respectively) (Table 1 ).

The frequency of the II genotype and I allele of $A C E$ gene in patients with Henoch-Schönlein purpura was higher than that of the control but the difference was not significant.

Studying joint interaction yielded significant results for two-locus analysis (TT CCL2/ II ACE and TT CCL2/ $\mathrm{CC} V E G F)$ in the overall analysis $(\mathrm{p}=0.000, \mathrm{OR}=6.009)$.

Table 2. Joint effects among -2518 C/T CCL2, -634C/G VEGF and ACE I/D genes

\begin{tabular}{|c|c|c|c|c|}
\hline $\begin{array}{c}\text { Genotypes } \\
\& \text { alleles }\end{array}$ & \multicolumn{2}{|c|}{$\mathrm{N}(\%)$} & $p$-value & $\begin{array}{l}\text { Odds } \\
\text { ratio }\end{array}$ \\
\hline ACE \& CCL2 & case & control & & \\
\hline$\| / T T$ & $11(23.40)$ & $5(6.76)$ & $0.000^{*}$ & 4.213 \\
\hline$\| / T C$ & $3(6.38)$ & $10(13.51)$ & $0.049^{*}$ & 0.436 \\
\hline ACE \& VEGF & case & control & & \\
\hline $\mathrm{ID} / \mathrm{GG}$ & $2(4.25)$ & $9(12.16)$ & $0.027^{*}$ & 0.321 \\
\hline CCL2 \& VEGF & case & control & & \\
\hline TT/CC & $12(25.54)$ & $4(5.40)$ & $0.000^{*}$ & 6.009 \\
\hline $\mathrm{TT} / \mathrm{GG}$ & $1(2.13)$ & $10(13.51)$ & $0.002^{*}$ & 0.139 \\
\hline $\begin{array}{l}\text { VEGF/ ACE/ } \\
\text { CCL2 }\end{array}$ & case & control & & \\
\hline $\mathrm{GC} / \mathrm{II} / \mathrm{TT}$ & $5(10.64)$ & $3(4.05)$ & $0.043^{*}$ & 2.821 \\
\hline $\mathrm{GC} / \mathrm{II} / \mathrm{AG}$ & $1(2.13)$ & $9(12.16)$ & $0.004^{*}$ & 0.157 \\
\hline
\end{tabular}

*p-value less than 0.05 .
Three-locus (TT CCL2/II ACE/ GC VEGF) joint effect was significantly different in 2 groups $(\mathrm{p}=0.043$, OR $=2.821)$ (Table 2).

\section{Discussion}

Different studies clearly show that genetic and non-genetic factors play important roles in the development of HSP disease. In this paper we focus on the possible interaction effects of SNPs from 3 different genes among HSP patients from Iranian Azeri Turkish population. We propose that an investigation of gene-gene interactions would expand our current understanding about the development of HSP disease. The impact of 3 different SNPs including CCL2 C-2518T, VEGF G-634C and ACE I/D was independently evaluated and their possible joint interactions were explored. Furthermore, different combinations of their genotypes were also studied in this cohort. On the basis of these results, individuals carrying $\mathrm{CC}$ genotype of VEGF G-634C ( $\mathrm{p}=0.007, \mathrm{OR}=2.448)$ and TT genotype of CCL2 C-2518T ( $\mathrm{p}=0.005$, OR $=2.159$ ) exhibited twice the susceptibility for developing the disease. Interestingly, studying joint interactions of these 2 genotypes (CC genotype of VEGF G-634C and TT genotype of CCL2 $\mathrm{C}-2518 \mathrm{~T}$ ) in our cohort showed that individuals with CCTT genotype have six times increased possibility of developing the disease $(\mathrm{p}<0.000, \mathrm{OR}=6.009)$. The association with $A C E \mathrm{I} / \mathrm{D}$ gene was only found when it was joint with CCL2 -2518 gene polymorphism. II genotype of $A C E$ in joined with TT genotype of CCL2 C-2518T showed statistically significant effect on the development of HSP disease ( $\mathrm{p}<0.000, \mathrm{OR}=4.213$ ).

HSP is known as a multi-factorial disease, thus the involvement of multiple SNPs from a variety of genes and their joint-interaction affecting the development of the disease is possible.

Pro-inflammatory cytokines and complement family are possible factors involved in the pathogenesis of HSP. Increased levels of VEGF have been reported in some systemic vasculitis such as Behcet's disease and HSP. $V E G F-634$ G/C polymorphism of this gene has been reported as a genetic variant that may contribute to the development of the disease. ${ }^{5,18}$

Rueda et al and Zeng et al. have already reported that the frequency of VEGF-634 C allele is significantly increased in HSP patients. ${ }^{10,19}$

Yu et al.'s results showed elevations of the chemokine MCP1 in patients with acute HSP and they reported that $\mathrm{T}$ allele of this polymorphism was associated with the disease. ${ }^{9}$ Increased risk of developing HSP for individuals carrying both CC genotype of VEGF G-634C and TT genotype of CCL2 C-2518T indicate that there is a possible gene-gene interaction between these 2 genotypes (additive effect) and this joint effect could be either between genes or their encoded proteins. 
Although some previous studies were unable to confirm any association between ACE I/D gene polymorphism and HSP disease, a study on a Chinese cohort have shown that the frequency of $\mathrm{D}$ allele was higher than that of control group..$^{12,20,21}$

The ACE I/D SNP was not associated with HSP in our population; however, joint interaction analysis of $A C E$ $I / D$ and CCL2 C-2518T showed a significantly higher frequency of II genotype of $A C E I / D$ in coexistence with TT genotype of CCL2 C-2518T in patients. This joint association shows the possible existence of epistasis between these two genes. Since endothelial cell activation and vasculitis of the small blood vessels occurs in HSP, $R A S$ genes including $A C E$ gene polymorphisms seem to be biologically and clinically relevant to the development of the disease.

CCL2 has also an important role in the development of auto-inflammatory disorders including HSP. Our study evaluates potential interaction of CCL2 and ACE genes.

This is the first pilot study that evaluated independent and joint interactions of these three polymorphisms (-2518 C/T CCL2, -634C/G VEGF and ACE I/D) in regards to the susceptibility to HSP disease.

\section{References}

1. Kamath N, Rao S. Henoch-Schönlein purpura: An update. Indian J Rheumatol. 2012;7:92-98.

2. Jithpratuck W, Elshenawy Y, Saleh H, Youngberg G, Chi D, Krishnaswamy $\mathrm{G}$. The clinical implications of adult-onset Henoch-Schönelin purpura. Clin Mol Allergy. 2011;7:92-98.

3. Rigante D, Castellazzi L, Bosco A, Esposito S. Is there a crossroad between infections, genetics, and Henoch-Schönlein purpura? Autoimmun Rev. 2013;12:1016-1021.

4. Yang YH, Lai HJ, Kao ChK, Lin YT, Chiang BL. The association between transforming growth factor-b gene promoter C-509T polymorphism and Chinese children with Henoch-Schönlein purpura. Pediatr Nephrol. 2004;19:972-975.

5. Topaloglu R, Sungur A, Baskin E, Besbas N, Saatci U, Bakkaloglu A. Vascular endothelial growth factor in Henoche-Schönlein purpura. J Rheumatol. 2001;28:2269e73.

6. Yang $\mathrm{YH}$, Huang MT, Lin SC, Lin YT, Tsai MJ, Chiang BL. Increased transforming growth factor-beta (TGF-beta)-secreting $\mathrm{T}$ cells and $\lg A$ anti-cardiolipin antibody levels during acute stage of childhood Henoche-Schönlein purpura. Clin Exp Immunol. 2000;122: 285-290.
7. Yang $\mathrm{YH}$, Huang $\mathrm{YH}$, Lin $\mathrm{YL}$, et al. Circulating IgA from acute stage of childhood HenocheSchonlein purpura can enhance endothelial interleukin (IL)-8 production through MEK/ERK signalling pathway. Clin Exp Immunol. 2006;144:247e53.

8. Pavkova Goldbergovaa M, Lipkovaa J, Paveka N, et al. RANTES, MCP-1 chemokines and factors describing rheumatoid arthritis. Molecular Immunology 2012;52:273-278.

9. $\mathrm{Yu} \mathrm{HH}$, Liu PH, Yang YH, et al. Chemokine MCP1/CCL2 and RANTES/ CCL5 gene polymorphisms influence Henoche Scho " nlein purpura susceptibility and severity. Journal of the Formosan Medical Association published on 21 December 2012.doi:10.1016/ j.jfma.2012.12.007

10. Zeng HS, Xiong XY, Chen YY, Luo XP. Gene polymorphism of vascular endothelial growth factor in children with Henoche-Schönlein purpura nephritis. Chinese Journal Of Contemporary Pediatrics. 2009;11: 417-421.

11. Nalbantoglua S, Tabelb Y, Mirc S, Serdaroglud E, Berdelia A. Association between RAS gene polymorphisms (ACE I/D, AGT M235T) and Henoche-Schönlein purpura in a Turkish population. Dis Markers. 2013;34:23-32.

12. Dudley J, Afifi E, Gardner A, Tizard EJ, McGraw ME. Polymorphism of the ACE gene in Henoch-Schönlein purpura nephritis. Pediatr Nephrol. 2000;14:218-220.

13. Yoshioka T, Xu YX, Yoshida $H$, Shiraga $H$, Muraki T, Ito K. Deletion polymorphism of the angiotensin converting enzyme gene predicts persistent proteinuria in Henoch-Schönlein purpura nephritis. Arch Dis Child. 1998;79:394-399

14. Miller SA, Dykes DD, Polesky HF. A simple salting out procedure for extracting DNA from human nucleated cells. Nucl Acids Res. 1988;16:1215.

15. Prior SJ, Hagberg JM, Paton CM, et al. DNA sequence variation in the promoter region of the VEGF gene impacts VEGF gene expression and maximal oxygene consumption. Am J Physiol Heart Cric Phisiol. 2006;5:848-855.

16. Bonyadi M, Mohammadian T, Rafeey M, et al. Chemokine MCP1/ CCL2 gene polymorphism influences Henoche-Schönlein purpura susceptibility in Iranian Azeri-Turkish patients. 2015;54:1269-1274.

17. Bonnet $F$, Patel $S$, Laville $M$, et al. Influence of the ACE gene insertion/deletion polymorphism on insulin sensivity and impaired glucose tolerance in healthy subjects. Diabete Care. 2008;4:789-794.

18. Cekmen M, Evereklioglu C, Er H, et al. Vascular endothelial growth factor levels are increased and associated with disease activity in patients with Behçet's syndrome. Int J Dermatol. 2003;42:870-875.

19. Rueda B, Perez-Armengol C, Lopez-Lopez S, Garcia-Porrua C, Martin J, Gonzalez-Gay MA. Association between functional haplotypes of vascular endothelial growth factor and renal complications in HenocheSchonlein purpura. J Rheumatol. 2006;33:69e73.

20. Amoroso A, Danek G, Vatta S, et al. Polymorphism angiotensin converting enzyme and severety of renal disease in Henoche-Schönlein patient Nephrol. Dial Transplant. 1998;13:3184-3188.

21. Liu D, Lu F, Zhai S, et al. Renin-angiotensin system gene polymorphisms in children with Henoche-Schönlein purpura in West China. $J$ Renin Angiotensin Aldosterone Syst. 2010;11:248-255. 